\title{
STUDI KEJADIAN THUNDER STORM PADA SAAT HUJAN LEBAT (STUDI KASUS KOTA PONTIANAK DAN SEKITARNYA)
}

Asyrofi ${ }^{1)}$

\author{
1)Badan Meteorologi Klimatologi dan Geofisika, Pontianak \\ Email : asyrofi_empi@yahoo.co.id
}

\begin{abstract}
Abstrak
Telah dilakukan penelitian untuk mempelajari tentang hubungan kejadian petir dengan curah hujan untuk mengetahui masa matang hingga punah suatu awan pada saat terjadi hujan lebat di kota Pontianak. Data yang digunakan pada penelitian ini adalah data kejadian petir yang diperoleh dari lihgtning detector dan data curah hujan hellman tahun 2012 s.d 2013 di stasiun meteorologi Supadio, stasiun maritim Pontianak dan stasiun klimatologi Siantan. Analisis kejadian petir pada saat hujan lebat digunakan untuk mengetahui fase pertumbuhan awan, dimana untuk setiap curah hujan lebih dari $5 \mathrm{~mm} / 15$ menit dikategorikan sebagai fase matang, sebelum dan setelahnya masuk dalam fase pertumbuhan dan fase punah. Hasil penelitian menunjukan bahwa nilai korelasi tertinggi antara kejadian petir dan curah hujan terjadi pada tanggal 10 Oktober 2012 di Stasiun klimatologi Siantan dengan nilai $r=0,82$ dan korelasi terendah terjadi pada tanggal 15 November 2012 di stasiun meteorologi Supadio dengan nilai $r=0,61$.
\end{abstract}

Kata kunci : Petir, Curah Hujan, Lightning Detector

\section{Abstract}

This research is conducted to study about the relationship between lightning events and rainfall to determine the stage of cloud formation, starting from mature stage until dissipating stage on heavy rain events in Pontianak. Data used in this research are lightning events obtained from lightning detector and rainfall data from Hellman rainfall recorder on 2012 until 2013 at Supadio Meteorogical Station, Pontianak Marine Meteorogical Station and Siantan Climatological Station. Analysis of lightning on heavy rain events is used to determine the cloud stage. While rainfall is recorded greater than $5 \mathrm{~mm}$ in 15 minutes, it is categorized as mature stage. On the other hands, the stage before mature is classified as growth stage, while the stage after mature is grouped as dissipating stage. The result shows that the highest correlation betwen lightning events and rainfall happened in Siantan Climatological Station $(r=0,82)$ on October 10th 2012, while the lowest correlation value $(0,61)$ happened in Supadio Meteorogical Station on November 15th 2012.

Keywords : Lightning, Rainfall, Lightning Detector

\section{Pendahuluan}

Kepulauan Indonesia yang terletak pada $7^{\circ}$ $\mathrm{LU}-12^{\circ} \mathrm{LS}$ dan $94^{\circ} \mathrm{BT}-142^{\circ} \mathrm{BT}$ merupakan daerah khatulistiwa atau daerah tropis dengan tingkat pemanasan dan kelembaban tinggi. Kondisi ini mengakibatkan potensi kejadian petir menjadi sangat tinggi dibanding dengan daerah sub tropis [1].

Petir/kilat merupakan gejala listrik alami dalam atmosfer yang tidak dapat dicegah yang terjadi akibat lepasnya muatan listrik baik positif maupun negatif yang terdapat di dalam awan [2]. Berdasarkan tempatnya, pelepasan muatan listrik dapat terjadi di dalam satu awan (Inter Cloud, IC), antara awan dengan awan (Cloud to Cloud, CC) ataupun dari awan ke bumi (Cloud to Ground, CG) [3].

Mayoritas petir di atmosfer berasosiasi dengan badai guruh konvektif [4]. Petir dapat dideteksi dari permukaan dan angkasa menggunakan sensor optik, gelombang radio elektrik ataupun gelombang magnetik yang dihasilkan oleh proses luah listrik dalam frekuensi tertentu [4], seperti Low Frequency (LF, LF, 30 s.d $300 \mathrm{kHz}$ ), Very Low Frequency $(V L F, 3$ s.d $30 \mathrm{kHz})$, Extremely Low Frequency (ELF, 30 s.d $300 \mathrm{~Hz}$ ), dan Very High Frequency (VHF, 30 s.d $300 \mathrm{MHz}$ [ [5].

Petir merupakan bagian yang tidak dapat dipisahkan dari proses dinamika atmosfer terutama mikrofisika awan, sehingga dapat dijadikan sebagai bagian karakteristik maupun identifikasi kondisi cuaca, pemahaman karakteristik kilat pada awan guruh akan memberikan gambaran struktur maupun perkembangan awan sehingga dapat membantu dalam melakukan analisis cuaca ekstrim yang menyertainya [6].

Pada penelitian sebelumnya kejadian cuaca ekstrim atau hujan lebat dianalisis 
menggunakan data petir dan curah hujan untuk melihat masa matang atau punah awan $\mathrm{Cb}$ [6]. Dalam penilitian ini penulis menggunakan data hujan helman pada saat terjadi hujan lebat yang dibagi menjadi per 15 menitan sebagai patokan untuk menentukan fase matang suatu awan pada saat kejadian hujan lebat, dimana untuk setiap curah hujan lebih dari $5 \mathrm{~mm} / 15$ menit dikategorikan sebagai fase matang, sebelum dan setelahnya masuk dalam fase pertumbuhan dan fase punah.

\section{Metodologi}

Data yang digunakan dalam penelitian ini adalah data petir selama dua tahun (2012 \& 2013) dengan resolusi 15 menitan menggunakan "lightning detector" yang terpasang di Stasiun Meteorologi Supadio Pontianak. Data sekunder lain yang digunakan adalah data curah hujan yang tercatat pada kertas pias yang diambil dari Hellman rain gauge dengan resoulusi temporal 10 menitan dari 3 lokasi pengamatan yaitu Stasiun Meteorologi Supadio, Stasiun Meteorologi Maritim dan Stasiun Klimatologi Siantan.

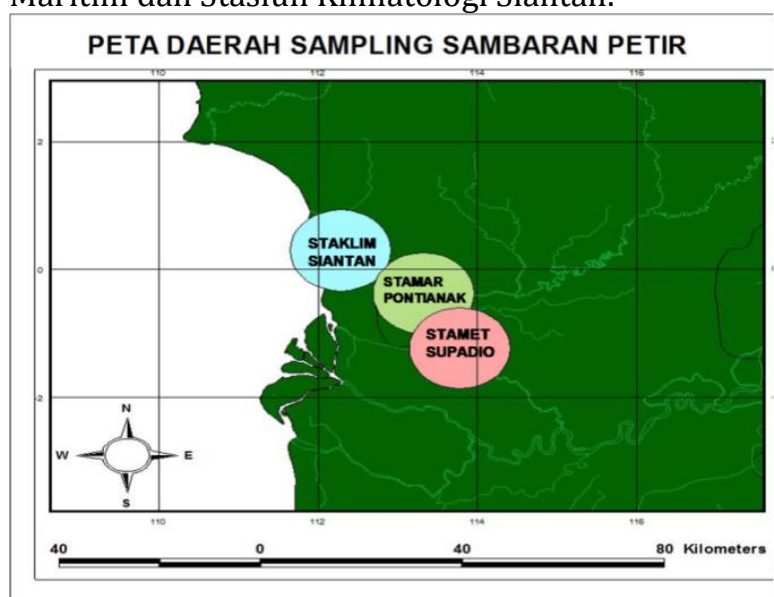

Gambar 1 Peta daerah sampling di 3 Stasiun pengamatan cuaca

Sistem deteksi petir yang digunakan adalah sistem deteksi dan analisa petir secara real-time menggunakan software Lightning/2000 [7] yang dirangkai dengan hardware Boltek Lightning Detection System dan sensor (storm tracker) yang terhubung dengan komputer, alat ini dapat mendeteksi strokes petir secara optimal sekitar 300 mil yang kemudian akan diplot secara otomatis dan real-time ke sistem, dimana semakin banyak strokes maka semakin maksimal penentuan posisi dari sistem.

Storm Tracker bekerja dengan mendeteksi sinyal radio yang dihasilkan oleh petir, dengan kata lain, antena Storm Tracker dapat memberikan informasi arah dan jarak thunderstorm yang dikalkulasikan dengan kekuatan sinyal yang diterima.

Data diolah menggunakan Lightning/2000 dengan ekstensi .ldc, selanjutnya dilakukan konversi ke dalam Google Earth untuk mendapatkan ekstensi .kml. Hasil konversi berikutnya dapat diterjemahkan oleh Excel untuk dibuat database.

Untuk mengurangi noise pada data yang dihasilkan, data yang digunakan dibatasi hanya di 3 lokasi penelitian dengan radius $10 \mathrm{~km}$ pada masing-masing stasiun, sehingga data petir yang dihasilkan mewakili kejadian di stasiun pengamatan. Untuk menganalisis kejadian petir dengan fase matang hingga punah suatu awan, pada penelitian ini menggunakan data petir dan curah hujan pada saat kejadian ekstrim/hujan lebat.

Data yg digunakan adalah data kejadian petir dan data hujan sebelum dan setelah terjadi hujan lebat yang dibagi menjadi setiap 15 menitan. Fase matang ditentukan berdasarkan batas atas pada intensitas hujan lebat yaitu dengan jumlah curah hujan $20 \mathrm{~mm} / \mathrm{jam}$ atau jumlah curah hujan yang mencapai lebih dari 5 $\mathrm{mm} / 15$ menit.

Secara garis besar, penelitian dilakukan berdasarkan pembuatan database, analisis time series dan analisis korelasi. Analisis time series diperlukan sebagai analisis awal dalam melihat struktur data, mengekstrak nilai-nilai statistika yang berarti dan karakteristik lain yang terkandung dalam data. Analisis korelasi menguji sejauh mana hubungan antar parameter secara kantitatif.

\section{Hasil dan Pembahasan}

\subsection{Analisis Petir dan Hujan pada saat Hujan Lebat di Stasiun Meteorologi Supadio}

Jumlah curah hujan per 15 menit yang terjadi pada tanggal 13 Juli 2012 di Stamet Supadio pada jam 8.45 WIB s.d jam 11.30 WIB dapat dilihat dari Gambar 2

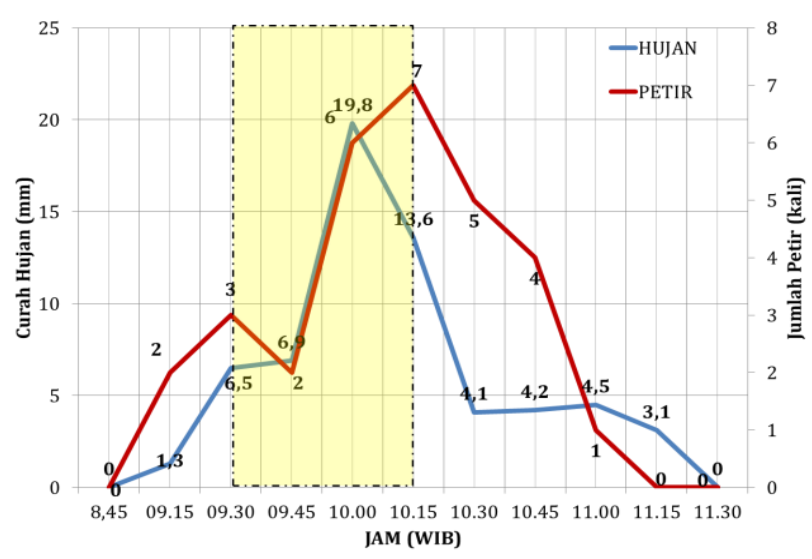

Gambar 2 Hujan dan Petir Stamet Supadio 13 Juli 2012 
jumlah curah hujan tertinggi terjadi pada jam 10.00 WIB sebesar 19,8 mm dengan jumlah sambaran sebanyak 6 sambaran, jumlah sambaran tertinggi terjadi pada pukul 10.15 WIB dengan jumlah sambaran sebanyak 7 sambaran dan curah hujan yang terukur pada jam tersebut sebesar 13,6 mm. Dari Gambar 2 menunjukan fase pertumbuhan awan terjadi sebelum jam 9.30 WIB hal ini terlihat dari jumlah curah hujan yang masih dalam katagori hujan ringan, fase matang terjadi selama 45 menit dengan intensitas hujan sangat lebat yang terjadi dari jam 9.30 s.d jam 10.15 dengan jumlah curah hujan selama periode tersebut sebesar 46,8 mm dan jumlah petir sebanyak 18 sambaran, setelah jam 10.15 awan mulai memasuki fase punah dengan jumlah curah hujan kurang dari $5 \mathrm{~mm} / 15$ menit. Jumlah Curah hujan yang terukur pada tanggal 13 Juli 2012 dari jam 8.45 s.d jam 11.30 sebanyak 64,0 $\mathrm{mm}$ dan jumlah petir sebanyak 30 sambaran. Dengan nilai korelasi sebesar 0,78.

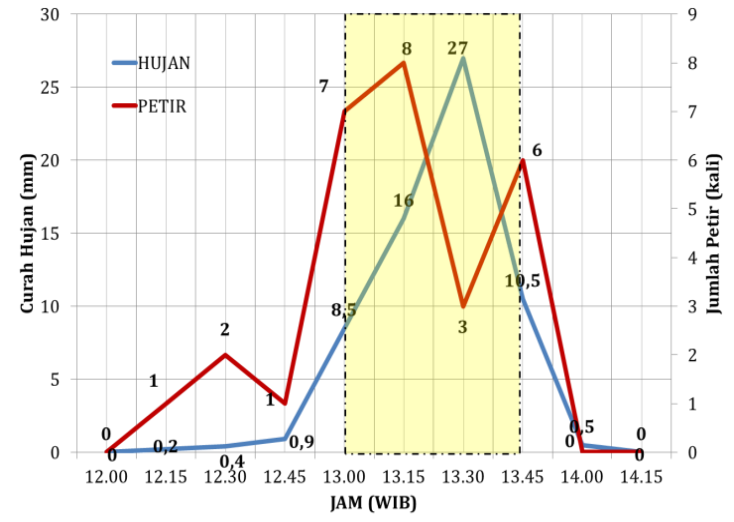

Gambar 3 Hujan dan Petir Stamet Supadio 15 November 2012

Dari Gambar 3 di atas, terlihat bahwa terdapat dua puncak kejadian petir yang juga bisa menunjukan bahwa awan terdiri dari multi sel. Jumlah curah hujan tertinggi terjadi pada jam 13.30 WIB dengan jumlah curah hujan sebesar 27,0 mm dan jumlah petir sebanyak 3 sambaran, jumlah sambaran tertinggi terjadi pada pukul 13.15 WIB sebanyak 8 sambaran dengan jumlah curah hujan sebesar 16,0 mm. Gambar tersebut juga menunjukan fase pertumbuhan awan terjadi sebelum jam 13.00 WIB hal ini terlihat dari jumlah curah hujan yang masih dalam kategori hujan ringan, fase matang dengan intensitas hujan sangat lebat terjadi selama 45 menit dari jam 13.00 s.d jam 13.45 dengan jumlah curah hujan selama periode tersebut sebesar $62,0 \mathrm{~mm}$ dan jumlah petir sebanyak 24 sambaran, setelah jam 13.45 awan mulai memasuki fase punah dengan jumlah curah hujan masuk dalam kategori hujan ringan. Jumlah Curah hujan yang terukur pada tanggal 15 November 2012 dari jam 12.00 WIB s.d jam 14.00 WIB sebanyak 64,0 mm dan jumlah petir sebanyak 28 sambaran, dengan nilai korelasi sebesar 0,61

\subsection{Analisis Petir dan Hujan pada saat Hujan Lebat di Stasiun Meteorologi Maritim Pontianak}

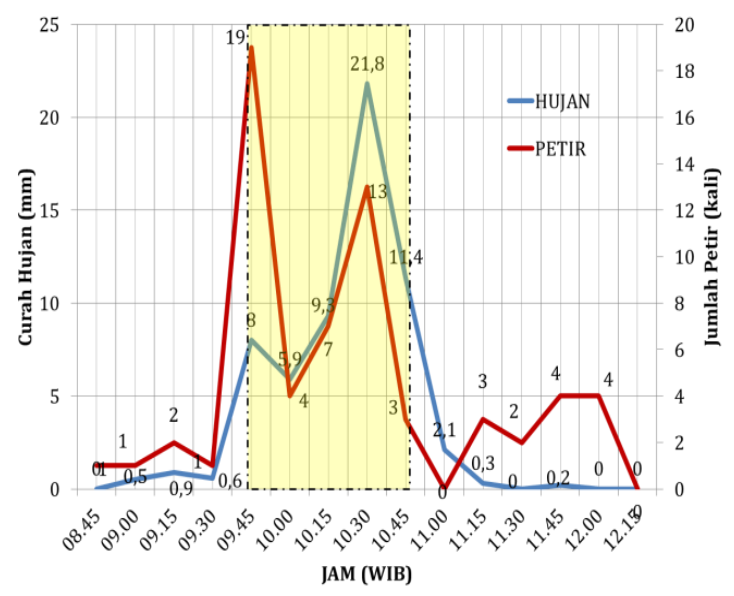

Gambar 4 Hujan dan Petir Stamar Pontianak 13 Juli 2012

Pada tanggal 13 Juli 2012, sambaran petir tertinggi terjadi lebih dulu sebelum curah hujan maksimum hal ini disebabkan karena sensor petir sudah bisa mendeteksi adanya aktifitas petir pada awan dalam wilayah penelitian sementara hujan yang turun belum mencapai stasiun, adanya dua puncak kejadian petir juga bisa menunjukan bahwa awan tersebut terdiri dari beberapa sel CB. Jumlah curah hujan tertinggi di Stasiun Maritim Pontianak terjadi pada jam 10.30 WIB dengan jumlah curah hujan sebesar 21,8 mm dan jumlah petir sebanyak 13 sambaran, jumlah sambaran tertinggi terjadi pada pukul 9.45 WIB sebanyak 19 sambaran dengan jumlah curah hujan sebesar 8,0 mm. Dari Gambar 4 menunjukan fase pertumbuhan awan terjadi sebelum jam 9.45 WIB hal ini terlihat dari jumlah curah hujan yang masih dalam kategori hujan ringan, fase matang terjadi selama 60 menit dari jam 9.45 s.d jam 10.45 dengan jumlah curah hujan selama periode tersebut sebesar $56,4 \mathrm{~mm}$ dan jumlah petir sebanyak 46 sambaran, setelah jam 10.45 awan mulai memasuki fase punah hal ini terlihat dari jumlah curah hujan setealah jam tersebut sebanyak 2,6 mm yang masuk dalam kategori hujan ringan. Jumlah Curah hujan yang terukur pada tanggal 13 Juli 2012 dari jam 8.45 WIB s.d jam 12.15 WIB sebanyak 61,0 $\mathrm{mm}$ dan jumlah petir sebanyak 64 sambaran, dengan nilai korelasi sebesar 0,65. 


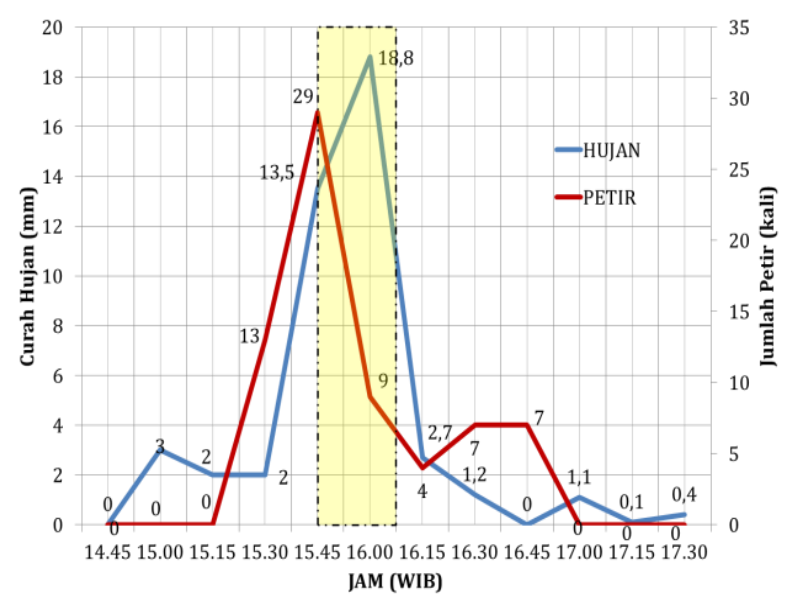

Gambar 5 Hujan dan Petir Stamar Pontianak 22 Januari 2013

Dari gambar 5 dapat diketahui kejadian hujan lebat cukup singkat terlihat dari daerah arsiran yang tidak begitu lebar yang menandakan bahwa sel awan CB juga tidak terlalu besar atau terkonsentrasi pada satu titik. Jumlah curah hujan tertinggi terjadi pada jam 16.00 WIB dengan jumlah curah hujan sebesar 18,8 mm dan jumlah petir sebanyak 9 sambaran, jumlah sambaran tertinggi terjadi pada pukul 15.45 WIB sebanyak 29 sambaran dengan jumlah curah hujan sebesar 13,5 mm. fase pertumbuhan awan terjadi sebelum jam 15.45 WIB dengan jumlah curah hujan sebelum jam tersebut berjumlah 7,0 $\mathrm{mm}$ yang masuk dalam kategori hujan sedang, fase matang dengan intensitas hujan sangat lebat terjadi selama 15 menit dari jam 15.45 WIB s.d jam 16.00 WIB hal tersebut mengindikasikan bahwa inti sel awan CB tepat berada di atas stasiun dalam kondisi yang sudah matang dengan jumlah curah hujan selama periode tersebut sebesar 32,3 mm dan jumlah petir sebanyak 38 sambaran, setelah jam 16.00 WIB awan mulai memasuki fase punah, hal ini terlihat dari jumlah curah hujan sebanyak $5 \mathrm{~mm} /$ jam yang termasuk dalam kategori hujan ringan. Jumlah Curah hujan yang terukur pada tanggal 22 Januari 2013 dari jam 14.45 WIB s.d jam 17.30 WIB sebanyak 44,8 $\mathrm{mm}$ dan jumlah petir sebanyak 69 sambaran, dengan nilai korelasi sebesar 0,62.

\subsection{Analisis Petir dan Hujan pada saat Hujan Lebat di Stasiun Klimatologi Siantan}

Hujan dengan intensitas sangat lebat terjadi dari awal turunnya hujan (shower), jumlah curah hujan tertinggi dan sambaran terbanyak terjadi pada jam 5.15 WIB, ini menandakan bahwa keberadaan inti sel awan CB tepat berada di atas Staklim Siantan dengan kondisi sudah matang, dengan jumlah curah

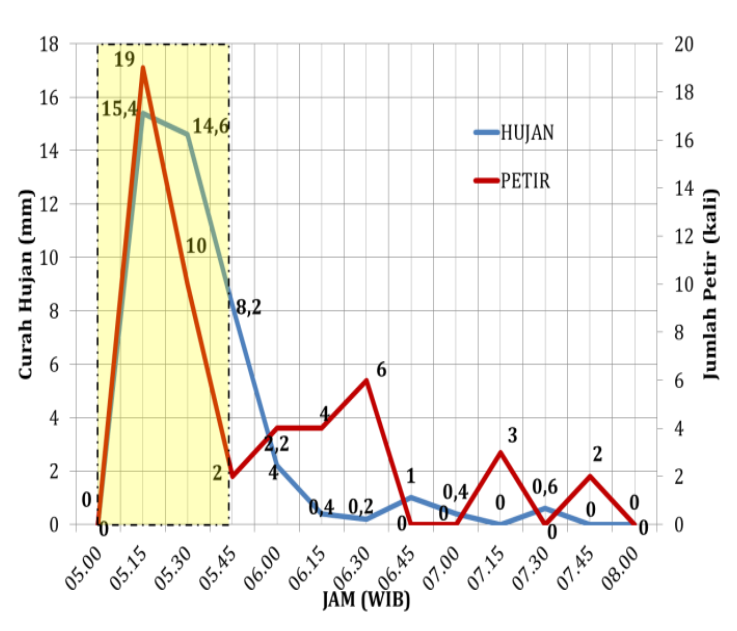

Gambar 6 Hujan dan Petir Staklim Siantan 10 Oktober 2012

hujan sebesar 15,4 mm dan jumlah petir sebanyak 19 sambaran, fase pertumbuhan awan terjadi sebelum jam 5.15 WIB sebelum turun hujan dan fase matang terjadi selama 30 menit dengan intensitas hujan sangat lebat terjadi dari jam 5.15 WIB s.d jam 5.45 WIB dengan jumlah curah hujan selama periode tersebut sebesar 38,2 mm dan jumlah petir sebanyak 31 sambaran, setelah jam 5.45 WIB awan mulai memasuki fase punah yang terlihat dari jumlah curah hujan kurang dari 5 mm/15 menit dan masuk dalam kategori hujan ringan setelah jam 6.15 WIB. Jumlah Curah hujan yang terukur pada tanggal 10 Oktober 2012 dari jam 5.00 WIB s.d jam 8.00 WIB sebanyak 43,0 mm dan jumlah petir sebanyak 50 sambaran, dengan nilai korelasi sebesar 0,82.

\section{KESIMPULAN}

Dari hasil pengolahan data dan analisis yang dilakukan, terdapat hubungan yang saling mempengaruhi antara kejadian petir dan jumlah curah hujan pada saat kejadian hujan lebat. Nilai korelasi tertinggi antara kejadian petir dan curah hujan terjadi pada tanggal 10 Oktober 2012 di Stasiun klimatologi Siantan dengan nilai $\mathrm{r}=0,82$ dan korelasi terendah terjadi pada tanggal 15 November 2012 di stasiun meteorologi Supadio dengan nilai $r=0,61$. Fase pertumbuhan awan (tumbuh, matang, punah) di Kota Pontianak dapat diketahui dari analisis kejadian petir dan curah hujan pada saat hujan lebat, dimana untuk setiap curah hujan lebih dari $5 \mathrm{~mm} / 15$ menit dikategorikan sebagai fase matang sedangkan sebelum dan setelahnya masuk dalam fase pertumbuhan dan fase punah. 


\section{DAFTAR PUSTAKA}

1. Tjasyono, B. HK, 2005. "Sains Atmosfir", ITB Bandung.

2. Hidayat, S. 1991. "Penentuan Harga Puncak Waktu Dahi Gelombang Arus Petir dari Pengukuran Medan Elektrik Jarak Jauh", Tesis Magister, Program Pasca Sarjana, Institut Tehnologi Bandung.

3. Pabla, A.S., 1981. "Sistem Distribusi Daya Listrik", Penerbit Erlangga, Jakarta.

4. Mac Gorman, D. and W. Rust (1998). "The Electrical Nature of Storms", Oxford University Press, New York.

5. Schumann, U. dan Huntrieser, H. (2007). "The global lightning-induced nitrogen xides source", Atmospheric Chemistry and Physics, 7:3823-3907.

6. Septiadi, D. dan Hadi, S. (2011). "Karakteristik Petir Terkait Hujan Lebat di Wilayah Bandung", Jurnal Meteorologi Dan Geofisika 12:163-170.

7. www.brothersoft.com/lightning-2000136009.html (diakses pada tanggal 21 Desember 2005). 